\title{
Coping Behavior and Difficult Life Situations of Russian School-Students With Different Intelligence Levels
}

\author{
Julia Babaeva \\ Lomonosov Moscow State University, Moscow, Russia. \\ E-mail: julybabaeva@gmail.com \\ Yuliya Briseva \\ National Research University - Higher School of Economics, Moscow, Russia. \\ E-mail: j.briseva@gmail.com \\ Anna Koltsova \\ Lomonosov Moscow State University, Moscow, Russia. \\ E-mail: anirk@mail.ru
}

\section{Doi:10.5901/ajis.2013.v2n3p489}

\section{Abstract}

The character of coping behavior (CB) and difficult life situations (DLS) of students with different levels and types (verbal or non-verbal) of intelligence were studied. The participants of the study were students from different Moscow schools $(N=60)$. Students with a high level of intelligence development prefer problem-focused coping strategies and understand DLS as situations requiring active steps, self-solution to the problem and self-management skills of controlling the situation. Students with lower level of intelligence prefer emotion-focused coping strategies and understand DLS as situations going beyond the control, requiring help and external support. Substantial aspects of coping vary depending on the dynamics of the level intellectually. Subjective esteems of "heaviness" of DLS depend on the intelligence level development and intelligence types.

Key words: coping behavior, coping strategies, difficult life situations (DLS), level of intelligence development, verbal and nonverbal intelligence.

\section{Introducion}

The role of intelligence in coping behavior has been debated for a long time. The diversity of opinions and contradictions in empirical data has led to the appearance of two essentially different positions about the role of intelligence in coping within the scientific community: intelligence as the source (resource) of difficult life situations (DLS) (Neihart, 1999; Preuss, Dubow, 2004).

High intelligence as a resource for the more successful coping. According to this view intellectually gifted children are considered as whose that effectively cope with difficulties and achieve a great success not only in school age but also in adult life and career. This becomes possible due to their high abilities that allow them to reach a deeper understanding of themselves and others. Here it is stressed that such a life well-being is not a necessary consequence of giftedness but becomes possible only with appropriate support of others and good environmental conditions.

High intelligence as a source of additional life difficulties and the particular sensitivities of gifted children to difficult life situations. It has been assumed that children with high intelligence are more vulnerable, sensitive and susceptible to stressors and they often unable to overcome stress effectively. With the fact of their high sensitivity it can be an obstacle not only for the development of outstanding abilities but also for the mental and physical health of these children.

Specific of personality of highly gifted children and their educational needs suggest specific requirements to the organization of work with them. It is necessary to provide a special system of care and support for gifted children that would take into account their outstanding abilities (Roedell, 1984). Thus, there is the need to revise the role of school (Renzulli, 1983; Roeper, 1989; Mazzoli Smith, Campbell, 2012), teachers and parents in the gifted children education (Kearney, 1989; Colangelo, Dettmann, 1983; Delisle, 2006).

The issues of giftedness in the Russian Federation in recent years are under the special attention and controlling. Besides the number of laws and regulations, educational and social initiatives, new schools and systems of monitoring and identifying of gifted children, in support of giftedness there has been developed the concept of giftedness. Being 
initiated by the Ministry of Education the concept summarizes the fundamental achievements of world science in the field of giftedness as well as practical experience of working with gifted children (Working concept of giftedness, 1998). Based on the humanistic orientation this concept deals with the difficulties that are faced by gifted children as well as positive aspects. Thus, the necessity of help and support of these children in their education and development is defined.

\section{Characteristics of coping behavior}

In general the researchers agree that students with differing levels of intelligence development have specific features of coping and DLS. High sensitivity of gifted and particularly highly gifted children leads to the fact that they are faced with their own specific problems (as perfectionism, interpersonal conflicts, alienation, etc). However, it clarifies, that under favorable circumstances gifted students capable of being more successful than their peers in DLS overcoming (Parenting the Gifted Child; Roedell, 1984; Roeper, 2008 ). Study process, family problems, difficulties with peers, high expectations of society are being called as the most difficult stressors for overcoming (Buescher, 1985; Compas et all, 1988; Rimm, 2003; Roedell, 1984).

According to existing data intellectually gifted children and adolescents have a wide range of coping strategies (Khazova, 2004; Kholodnaya \& Aleksapol'sky, 2010), tend to quick and efficient solutions to problems and action-oriented approaches to solving problems (Buescher, 1985), mostly select productive strategies (Nikolskaya \& Granovskaya, 2000), focus on solving the problem and work hard to achieve (Frydenberg, 1997; Sierralta, 2000; Preuss, Dubow, 2004). They also less resort to socially disapproved strategies (Nikolskaya \& Granovskaya, 2000), distancing, seeking social support, ignoring the problem, wishful thinking, negative tension reduction (as smoking or alcohol use) (Frydenberg, 1997; Khazova, 2004; Sierralta, 2000).

However, the empirical data evidence the relationship between the intelligence and productive or effective coping remain controversial. For example, studies on Russian samples have not revealed any direct relations between the psychometric intelligence scores, creativity, intellectual achievements and productive strategies (Sierralta, 2000; Khazova, 2004). Yet, the high level of non-verbal creativity reduces the risk of non-effective coping, as well as preferring of "non-productive" strategies. Comparing to their peers coping of gifted students have been less rigid, more mobile and focused on the situation which led the authors to the conclusion about the existence of coping qualitative features of gifted school-students and more generally about the positive role of non-verbal intelligence and creativity in coping behavior (Khazova, 2004).

It is also shown that at high rates of intelligence emotional and social strategies are used on a par with problemoriented (Kholodnaya \& Aleksapol'sky, 2010). The authors note that any strategy may appear as effective or ineffective. For example, for the problem-oriented strategies the "productive" aspect is keeping the sense of self-efficacy, while "unproductive" ones includes such negative effects as the illusion of control and fast resource exhaustion; avoidance strategies may cause the formation of protective-type behavior but at the same time allows person to accumulate the mental resources, etc. The higher the intellectual maturity is (cognitive, conceptual, academic ability), the wider range of strategies uses the person, mainly preferring emotional and social coping strategies, - the authors assumed (Kholodnaya \& Aleksapol'sky, 2010).

Thus, the authors state that the division of coping strategies into "bad" or good, "productive" or "unproductive" is not quite correct. During interpretation it should be taken into account the specific of situation when these strategies were applied (Khazova; 2004; Kholodnaya \& Aleksapol'sky, 2010).

In our study we analyzed the intellectual aspects of giftedness and their relationship with overcoming of difficult situations.

The aim of the study was to investigate the character of coping behavior and difficult life situations of students with different levels of intellectual development, and different verbal and non-verbal intelligence levels.

\section{Methods}

The level and type of intelligence was tested by Raven's Standard Progressive Matrices (L. Penrose, J. Raven ) ( Raven et al , 2002), and Amthauer's Test of Intelligence Structure (TSI),subtests Analogies and Similarities (Eliseev , 2003).

DLS were studied by the author's methodic "DLS" (Yu.D. Babaeva, E.Yu. Meshalkina), allowing to identify: a) an understanding of DLS (in free form students were asked to give their definition of DLS), b) the most frequently appearing DLS in life, and c) a subjective estimate of difficulty for each of these DLS (Babaeva, 1996). 
Coping was measured using the Russian adaptations of methodic WCQ - Ways of Coping Questionnaire (R. Lazarus \& S. Folkman) (Kryukova et al, 2005), and COPE (C.S. Carver, M.F Scheier, \& J.K. Weintraub) (Gordeeva et al , 2010).

\section{Participants}

60 high-school students of Moscow schools (17 boys, 43 girls aged 15 to 16 years) are involved in this study. Obtained data were analyzed within general sample and between the contrasting groups formed based on results of Raven's method. Group I (38\% of the general sample) included students with the highest rates of non-verbal intelligence (M +

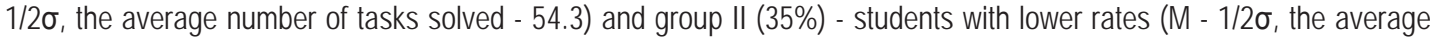
number of tasks solved - 42.4). The results of "intermediate" group (27\%) with normal intelligence were considered during the analysis of general sample results, but were not considered during the study of the differences. When comparing the types of intelligence data was also analyzed based on the Amthauer's test results. As a result, 4 subgroups with different combination of verbal and non-verbal intelligence rates were identified: $(A)$ group with high levels of non-verbal and verbal intelligence (NVI and $\mathrm{VI}$ ), $17 \%$; (B) with high NVI and medium VI, $15 \%$; (C) medium NVI and high VI, $12 \%$; (D) both medium NVI and VI, $23 \%$. Data were analyzed using SPSS 17.0 for Windows program. To clarify the content and features of DLS experiences students were asked to give an interviews.

\section{Results and discussion}

\section{The DLS specific.}

The structure of DLS.

The results showed that Russian students were defined DLS as a rather wide range of situations, where the educational sphere, interpersonal, some intrapersonal problems, and death of relatives are prevalent. The "heaviness degree" of these DLS was also quite high, and in most cases subjective evaluation was below the average. The list of situations faced by students with different intelligence levels and their subjective esteem of difficulties are presented in Table 1.

Table 1. The DLS structure and the subjective esteems of their difficulties

\begin{tabular}{|c|c|c|c|c|c|}
\hline \multirow[t]{3}{*}{ № } & \multirow{3}{*}{ DLS } & \multicolumn{4}{|c|}{ Comparing groups } \\
\hline & & \multicolumn{2}{|c|}{ Group I } & \multicolumn{2}{|r|}{ Group II } \\
\hline & & Quantity (\%) & $\begin{array}{l}\text { Subjective esteem of } \\
\text { "heaviness" (average } \\
\text { scores, max. }=10 \text { ) }\end{array}$ & $\begin{array}{c}\text { Quantity } \\
(\%)\end{array}$ & $\begin{array}{c}\text { Subjective esteem of } \\
\text { "heaviness" (average } \\
\text { scores, max. }=10 \text { ) }\end{array}$ \\
\hline 1 & $\begin{array}{l}\text { Financial and living } \\
\text { conditions }\end{array}$ & 8,7 & 5 & 19,0 & 6 \\
\hline 2 & Educational sphere & 60,9 & 7,5 & 28,6 & 6 \\
\hline 3 & Hobbies & - & - & 4,8 & 4 \\
\hline 4 & Interpersonal relations & & & & \\
\hline
\end{tabular}




\begin{tabular}{|c|c|c|c|c|c|}
\hline 4.1 & Quarrels with parents & 60,9 & 9,5 & 61,9 & 7 \\
\hline 4.2 & Quarrels with friends & 56,5 & 6 & 33,3 & 5 \\
\hline 4.3 & Relationships with the opposite sex & 21,7 & 6,5 & 42,9 & 6 \\
\hline 5 & Interpersonal problems & & & & \\
\hline$\overline{5.1}$ & $\begin{array}{l}\text { The lack of resources for ideas } \\
\text { implementation }\end{array}$ & 8,7 & 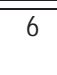 & - & - \\
\hline 5.2 & Laziness & - & - & 19,0 & 7 \\
\hline 5.3 & Fears of non-meeting the expectations & 13,0 & 6 & - & - \\
\hline 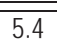 & Plans for the future & 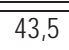 & 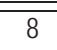 & 19 & $\overline{5}$ \\
\hline 6 & Health & 21,7 & 9 & 14,3 & $\overline{9}$ \\
\hline 7 & Bad habits & & & & \\
\hline 7.1 & Overeating & - & - & 4,8 & 10 \\
\hline 7.2 & Computers & - & - & 4,8 & 8 \\
\hline 8 & Relatives death & 26,1 & 9 & 42,9 & 9 \\
\hline
\end{tabular}

\section{Defining of DLS.}

In general students define DLS as a complex, multidimentional phenomenon requiring specific actions for their overcoming. The data that gained by the group comparison confirmed the hypothesis about the specific understanding of DLS by students with different levels of intellectual development.

Students of the first group define DLS as stressful, unusual situation for a person, causing a negative mood and bad emotions, taking away the fullness of life (emotional aspect). At the same time, this are situations teaching people (cognitive aspect), and forcing them to active steps - choice, self-solution to the problem, concentration, self-management skills of controlling the situation (personal aspect associated with the pursuit of self-dependence).

Students of the second group by emotional aspect define DLS as situations, negatively affecting the livelihood, suppressing person. According to them, these are situations caused by external reasons and circumstances that are not completely take into control. Overcoming of DLS requires special tools, knowledge and skills (cognitive aspect). Another distinguishing feature of this group is emphasizing the need for care, support, family involvement in most definitions: one cannot and should not deal with difficult situations alone (personal aspect related to the lack of independence and focus on care and support in DLS overcoming).

In our point, the fact that students have different understandings of DLS and action needed for overcoming of difficult situations (independence or external support), is corresponds with the existing data about preferring coping ways (based on Lazarus \& Folkman, Fraydenberg \& Lewis classifications): problem-oriented or constructive within students with high level of intelligence development and emotion-focused or seeking social support within their peers.

\section{Differences in DLS content.}

The suppose of the DLS specific content has been also confirmed. In both groups, the most frequent and "heavy" DLS 
could match by name, however, analysis showed them having different contents.

DLS in educational sphere for students of the first group was closely related to internal, emotional feelings, and their specific content included public performances, participate in contests, competitions, the successes achieved, etc. These students are characterized by having high standards for themselves, their activity goes beyond the standard school situations.

DLS in learning sphere for students of the second group was correlated rather with the achievement of certain external regulatory parameters and the content included taking exams, fixing bad grades, etc.

Referring to interpersonal sphere, students of all groups were deeply concerned about quarrels with parents. However, while for the second group students this quarrels mostly related to their parents divorces, or bad habits (external factors), students of the first group rather concerned about excessive demands, parent's pressure, fears about non-meeting their expectations (internal factors). Note that the data on the family role and support in our study have been quite different. In various responses relationships with parents could be the strong support as well as an additional stressor and source of anxiety.

Some students from the second group are paying special attention to certain DLS related to their own bad habits "addictions", according to their point (eg, "overeating" and "computers"), while in the group with higher level of intellect similar DLS were not presented. These differences between two groups analyzed, in our opinion, could be explained by the character of volitional control. It could be assumed that exactly intelligence development facilitates more comprehensive, conscious control over the behavior, which is indirectly confirmed by the specific understanding of DLS by students.

\section{Subjective "heaviness" esteems.}

Generally, subjective "heaviness" of DLS was estimated by students of the first group higher than the second one (Table 1). The differences were statistically significant in two spheres - academic and interpersonal ( $p<0.01$ by Mann-Whitney test). Again, the most distinct differences in the "heaviness" esteems of DLS were marked for situations related to the activity and self-attitude. Activity of most students of the first group tends to go beyond the regular school situations (competitions, contests, self-development etc.), also they are characterized by very high standards for themselves and the results achieved. At the same time, for many of their peers from the second group "heaviness" of DLS rather related to the "typical" problems (meeting deadlines, fixing the unsuccessful effects, etc.), and, as a rule, self-demands and evaluation of results, are not so categorical. In this case, it can be assumed that the specific of DLS may be also related to the individual locus of control - internal or external.

The difference in DLS content and "heaviness" was also appeared depending on the type of intelligence. Students from group B having a high non-verbal intelligence (NVI ) combined with a low verbal intelligence (VI) comparing to their peers apparently have more difficulties in communication and interpersonal relationships spheres. The difficulties of students in the group B, were largely caused by their lack of verbal, communication and social skills, and overcome in a particular way. For example, the need to communication is achieved by belonging to tight social circle, where these students feel comfortable and confident. At the same time, the interruption of regular living conditions (quarreling with relatives, friends removing, changing of the communicative context, etc.) causes intense feelings associated to the necessity of changing the communication formed, establishing new contacts, etc. Students of this group prefer acting independently as possible without help or support, as these strategies require them active communication and interaction, so their lack of competence turns itself into a difficult situation requiring overcoming. Additionally, students as a rule realize and deeply experienced the luck of their competences. More fulfill understanding of student's choices of behavior strategies need further researches, however, even at this stage, it is showed the importance of individual features taking into account while discussing problematic of "productivity" or "efficiency" of coping used.

\section{The specialties of coping behavior}

\section{Preferred strategies.}

Within the whole group students with different intelligence levels use a wide range of coping strategies. In case of both methods of diagnosis the coping strategies preferred were problem-oriented (Active coping and Planning, Accepting Responsibility, Planful Problem Solving, Self-controlling), emotion-focused (Seeking Emotional Social Support, Focus on and Venting of Emotions, Seeking Instrumental Social Support, Seeking Social Support), and also some constructive 
strategies of cognitive adaptation (Positive Reinterpretation and Growth, Positive Reappraisal). Practically unusable were such "ineffective" strategies as Alcohol/Drug Use, Denial, Escape-Avoidance and Religion.

In comparing groups, as data showed, the students with high intelligence level generally distinguished by higher rates of the strategies belonging to problem-oriented range (Active coping, Suppression of Competing Activities, Planful Problem Solving, Self-Controlling). The students of second group had higher rates for emotional- and social-focuced strategies (Seeking Emotional Social Support, Focus on and Venting of Emotions, Seeking Instrumental Social Support, Seeking Social Support, Seeking Social Support), and cognitive adaptation strategies (Positive Reinterpretation and Growth, Positive Reappraisal). Average scores of coping scales of both methods, and significant differences between groups (according to Mann -Whitney test) are presented in Table 2.

Table 2. COPE and WCQ methods average scores and the differences in coping between groups

\begin{tabular}{|c|c|c|c|c|}
\hline Coping Strategies & $\begin{array}{l}\text { General } \\
\text { Sample }\end{array}$ & Group I & Group II & $\begin{array}{c}\mathrm{U} \text { (Mann-Withey } \\
\text { test) }\end{array}$ \\
\hline \multicolumn{5}{|l|}{ COPE (average scores) } \\
\hline Positive Reinterpretation and Growth & 12.3 & 11.5 & 13.0 & $149.000^{*}$ \\
\hline Mental Disengagement & 8.3 & 7.5 & 9.2 & $140.500^{*}$ \\
\hline Focus on and Venting of Emotions & 10.1 & 9.0 & 10.3 & $154.000^{*}$ \\
\hline Seeking Instrumental Social Support & 9.8 & 9.3 & 10.4 & 198.500 \\
\hline Active Coping & 11.7 & 12.1 & 11.0 & 182.500 \\
\hline Denial & 7.4 & 6.9 & 8.0 & 180.500 \\
\hline Religion & 6.9 & 5.8 & 7.5 & $144.000^{*}$ \\
\hline Humor & 9.4 & 9.0 & 10.0 & 195.500 \\
\hline Behavioral Disengagement & 7.5 & 7.5 & 7.6 & 240.000 \\
\hline Restraint Coping & 9.4 & 8.8 & 10.1 & 163.500 \\
\hline Seeking Emotional Social Support & 10.4 & 9.1 & 10.7 & 209.500 \\
\hline Alcohol/Drug Use & 5.9 & 5.6 & 6.2 & 228.500 \\
\hline Resignation/Acceptance & 9.5 & 9.2 & 9.5 & 230.500 \\
\hline Suppression of Competing Activities & 9.0 & 9.5 & 8.5 & 172.000 \\
\hline Planning & 11.4 & 11.6 & 11.4 & 214.500 \\
\hline \multicolumn{5}{|l|}{ WCQ (\%) } \\
\hline Confrontive Coping & 51.7 & 48.7 & 53.2 & 199.000 \\
\hline Distancing & 44.9 & 42.0 & 49.2 & 168.500 \\
\hline Self-Controlling & 54.4 & 59.6 & 53.1 & 181.500 \\
\hline Seeking Social Support & 54.3 & 49.0 & 57.1 & 191.500 \\
\hline Accepting Responsibility & 58.3 & 60.5 & 59.9 & 237.500 \\
\hline Escape-Avoidance & 43.2 & 39.7 & 47.4 & 162.000 \\
\hline Planful Problem Solving & 56.3 & 59.2 & 55.8 & 227.000 \\
\hline Positive Reappraisal & 54.6 & 52.2 & 59.6 & $156.500^{*}$ \\
\hline
\end{tabular}

Intellectual scores dynamics and coping preferred.

Rank correlation analysis showed that the most marked trend in coping preference appeared referring to coping character: when intelligence scores raised, there was increased the frequency of using copings including reflective moments, rethinking, and reduced the frequency of using accepting, non-critical copings. Thus, in the first group with an increasing of IQ increases the frequency of preferring strategies Active Coping (COPE) and Distancing (WCQ), and reduces the frequency of preferring strategies Mental Disengagement, Denial, Religion ( COPE). In the second group increasing of IQ scores reduced the frequency of using such strategies as Positive Reinterpretation and Growth (COPE) and Accepting Responsibility (WCQ). The obtained data are presented in Table 3. 
Table 3. Correlations between intelligence and coping scores

\begin{tabular}{|c|c|c|}
\hline Coping Strategies & $\underset{r}{\text { Group I, }}$ & Group II, r \\
\hline \multicolumn{3}{|l|}{ COPE } \\
\hline Positive Reinterpretation and Growth & 0.214 & $-0.416^{*}$ \\
\hline Mental Disengagement & $-0.460^{*}$ & 0.163 \\
\hline Focus on and Venting of Emotions & 0.010 & 0.368 \\
\hline Seeking Instrumental Social Support & -0.067 & -0.119 \\
\hline Active Coping & $0.453^{\star}$ & -0.248 \\
\hline Denial & $-0.542^{\star}$ & -0.002 \\
\hline Religion & $-0.529 *$ & 0.017 \\
\hline Humor & -0.060 & -0.032 \\
\hline Behavioral Disengagement & -0.385 & 0.391 \\
\hline Restraint Coping & 0.027 & -0.088 \\
\hline Seeking Emotional Social Support & 0.198 & -0.167 \\
\hline Alcohol/Drug Use & -0.409 & 0.043 \\
\hline Resignation/Acceptance & 0.208 & 0.198 \\
\hline Suppression of Competing Activities & 0.223 & -0.129 \\
\hline Planning & -0.410 & -0.105 \\
\hline \multicolumn{3}{|l|}{ WCQ } \\
\hline Confrontive Coping & -0.163 & -0.124 \\
\hline Distancing & $0.460^{*}$ & -0.309 \\
\hline Self-Controlling & 0.073 & -0.169 \\
\hline Seeking Social Support & -0.253 & 0.427 \\
\hline Accepting Responsibility & 0.312 & $-0.563^{\star *}$ \\
\hline Escape-Avoidance & 0.253 & -0.298 \\
\hline Planful Problem Solving & -0.077 & 0.012 \\
\hline Positive Reappraisal & -0.410 & -0.140 \\
\hline
\end{tabular}

\section{Findings}

1. There were identified specific features of DLS for students with different levels of intelligence. This specificity appears as an understanding of DLS and overcoming actions (independence and control VS the need for support and the inability of controlling), and specific content and subjective esteem (activity going beyond the regular school situations, high standards on themselves and the quality achieved results VS "typical" situation and targets to achieve nominal statutory results).

2 All groups participated in the study are characterized by a wide range of coping strategies the mostly preferred strategies are problem-focused and emotion-focused, while the "ineffective" strategies are barely used. Students with the high level of intelligence development in general more likely use problem-focused strategies, while their peers with lower scores tend to use more often emotion-focused strategies. As these differences were significant only concerning to emotion-focused strategies, the assumption about the presenting of differences in strategies choice was confirmed only patricianly. Thereby the results are needed further clarification.

3 Preference of certain coping varies with the changing of intellectual scores: in case of their increasing increases the frequency of using copings with reflexive and rethinking component, and reduces the frequency of using accepting, "noncritical" coping. The obtained results are consistent with data of other researchers, including established in Russian samples, about the preference and frequency of different strategies using (productive or unproductive, effective or ineffective, problem-focused or emotion-focused) by students with different levels of intellectual development.

\section{Conclusion}

The conducted study allowed to reveal a number of features in coping and DLS (preferences in strategies selection, subjective esteems, understanding of the content and character of DLS experience) that distinguish students with different intelligence types or scores of intellectual development. Holistic understanding of DLS and coping patterns (especially, questions about how gifted people subjectively percept and overcome DLS) requires further investigations. 
Yet, at this stage the marked features allow to define certain tasks as about the educational environment organization, forming of work with gifted students and their parents.

\section{References}

Rabochaya Kontseptsiya Odarennosti [Working Concept of Giftedness] (2003). Ed. by Bogoyavlenskaya D.B., Shadrikov V.D., Babaeva Yu.D. или J.D?, Brushlinskiy A.V. M.: The Ministry of Education of the Russian Federation, 2nd ed.

Gordeeva, T.O., Osin, E.N., Rasskazova, E.A., Sychev O.A., \& Shevyakhov, V.V. (2010). Diagnostika koping-strategiy: adaptatsiya oprosnika COPE. [Measurement of Coping Strategies: The Russian Adaptation of COPE Test]. Psikhologiya stressa $i$ sovladayushchego povedeniya $v$ sovremennom rossiyskom obshchestve [The Psychology of stress and coping in modern Russian society]. Proceedings of II International Science Conference, Kostroma, 23-25 sept. 2010, 195-196.

Raven, J., Raven, J.C., \& Court, J.H. (2002) Manual for Raven's Progressive Matrices and Vocabulary Scales, (translated from English). Moscow: Cogito Center.

Eliseev, O.P. (2001). Praktikum po psikhologii lichnosti/Test struktury intellekta R.Amtkhauera (TSI) [Workshop on Personality Psychology. Amthauer's Intelligence Structure Test (TSI)]. St. Petersburg: Piter.

Kryukova, T. L., \& Kuftyak, E.V. (2007) Oprosnik sposobov sovladaniya (adaptatsiya metodiki WCQ) [Survey of Coping Ways (Adoptation of WCQ Questionnaire)]. Zhurnal prakticheskogo psyhologa, (3), 93-112.

Nikolskaya, I.M., \& Granovskaya, R.M (2001) Psikhologicheskaya zashchita u detey [Psychologycal Protection in Children]. St. Petetsburg: Rech'.

Sierralta Z. H. Osobennosti psikhicheskikh resursov lichnosti v rannem yunosheskom vozraste: koping-strategii, zashchitnyye mekhanizmy, sotsial'nyy intellekt i obshchiy intellekt [Features of mental resources of person in early adolescence: coping strategies, defense mechanisms, social intelligence and general intelligence]. Dissertation for the degree of candidate of psychological sciences.

Khazova, S. A. (2004). Coping behavior by gifted senior pupils. Psikhologicheskii Zhurnal, 25(5), 59-69.

Kholodnaya, M. A., \& Aleksapol'sky, A. A. (2010). Intellectual abilities and coping strategies. Psikhologicheskii Zhurnal, 31(4), 59-68.

Buescher, T. M. (1985). A framework for understanding the social and emotional development of gifted and talented adolescents. Roeper Review. 8(1), 10-15.

Colangelo, N., \& Dettmann, D. (1983). A review of research on parents and families of gifted children. Exceptional Children, 50(1), 2027.

Compas, B. E., Malcarne, V. L., \& Fondacaro, K. M. (1988). Coping with stressful events in older children and adolescents. Journal of Consulting and Clinical Psychology, 56(3), 405-411.

Delisle, J. R. (2006). Parenting Gifted Kids: Tips for Raising Happy and Successful Children. Prufrock Press Inc.

Frydenberg, E. (1997). Adolescent coping. Theoretical and Research Perspectives. London; New York: Routledge.

Goerss, J., Sornik, M., \& Kearney, K. Parenting the Gifted Child:

http://wholelifecounselling.com/counselling/parenting-the-gifted-child/

Kearney, K. (1989). Parenting highly gifted children: The challenges, the joys, the unexpected surprises. CAG Communicator, 19(2), 1012.

Mazzoli Smith, L \& Campbell, J. R. (2012) Families, Education and Giftedness: Case Studies in the Construction of High Achievement. London and New York: Sense Publishers.

Neihart M. (1999). The Impact of Giftedness on Psychological Well-Being: What Does the Empirical Literature Say? Roeper Review. 22(1) $10-17$.

Renzulli, J. S. (1983). Guiding the Gifted in the Pursuit of Real Problems: The Transformed Role of the Teacher. The Journal of Creative Behavior, 17(1) 49-59.

Rimm, S (2003). Social Adjustment and Peer Pressures for Gifted Children: http://www.davidsongifted.org/db/Articles id 10125.aspx

Roedell W. (1984). Vulnerabilities of highly gifted children. Roeper Review, 6(3), 127-130.

Roeper, A. (1989). Ethics education for the gifted. The Education Digest, 54(6), 37-39.

Roeper, A. (2008). Global awareness and gifted children: Its joy and history. Roeper Review, 30(1), 8-10.

Preuss L., \& Dubow E. (2004).A comparison between intellectually gifted and typical children in their coping responses to a school and a peer stressor. Roeper Review, 26(2), 105-111. 


\title{
Input-Output Interplay in Indonesian EFL Classrooms: A Conversational Analytical Study
}

\author{
Yetti Zainil \\ Deakin University \\ Melbourne, Australia \\ Doi:10.5901/ajis.2013.v2n3p497
}

\begin{abstract}
Although classroom interaction has received a great deal of focus during the last 40 years, its investigation from a conversation analytic stance using video recordings and stimulated recall interviews is rather limited, especially at the primary schools level. This paper presents the findings of a study on actual classroom practices in primary schools in West Sumatra, Indonesia, specifically, the language used by teachers and its impact on the language used by students in EFL classrooms. Taking as a basic premise that exposure to the foreign language is conducive to language learning, transcript of classroom discourse were analysed. This will contribute to research on classroom interaction by elucidating various aspects of turn-taking and sequence organization of talk at school, and by specifying the exact constraints under which participants -teachers and students operate. The classroom data presented reveal teachers' variation and frequency range in oral input and students' output. There was a modest use of $L 1$ and a greater impact of the language used by teacher on students language output. The results suggest that students' language output was influenced by teachers' language choice. While not indicative of a cause-effect relationship, teachers might wish to consider encouraging quality of her target language use as well as quantity.
\end{abstract}

Key words: Conversation analysis, teachers' input, students' output, language foreign language classroom.

\section{Introduction}

English was introduced as an elective subject into elementary schools in Indonesia in 1990. However, at that time, there was no legislation regarding policy on teaching qualifications for English language teachers, and no guidelines on English language teaching and learning at the elementary school level. The 1994 English curriculum document aimed to support a pathway towards global competitiveness (Depdikbud 1993) and highlighted the importance of communicative competence as the main goal of English foreign-language learning in Indonesian elementary schools.

In 2004, the Ministry of Education of Rpublic of Indonesia published a new curriculum, the 2004 Curriculum which is well known as the Competence Based Curricullum [Kurikulum Berbasis Kompetensi-KBK]. This curriculum, shortly after, in 2006, was modified in such a way as to highlight the importance of using English (TL) as the main language input in the language classroom (Diknas 2006).

However, little is known about the practice of teaching English in elementary schools in Padang, and available information is based largely from anecdotal evidence. One question of importance in the context of achieving the aim of communicative competence among students is the language that is used most in classroom interaction. In Padang, most classes are teacher-fronted (see Musumeci 1996), where the teacher leads the class and provides the main source of language input for students. Students receive an average of 70 minutes of English instruction per week. The teachers are non-native speakers of the TL (English), and there is virtually no communicative need to use English outside the classroom. In fact, students do not hear much spoken English either inside or outside the classroom (Diknas 2010). For the aforementioned reasons, exposure to English in use in Padang is limited, in both social and educational settings. Accordingly, the issue of the language employed in teaching EFL classes in West Sumatra, and more generally across Indonesia, deserves serious attention. This paper examines the relationship between teacher input in the target language and its influence on students' output in terms of language choice (SL or TL) in EFL classrooms at the primary schools level in Padang, West Sumatra, Indonesia. 


\section{Literature review}

\section{Input-Output interplay in EFL classrooms}

The similarity in the processes involved in first language/second language (hereafter referred to as L1/SL respectively) and target language (TL) acquisition is not known. However, many TL learners rely, in the same way as first language (L1/SL) learners, on oral input as the primary source of the target language (Krashen 1982, Morata \& Coule 2012, Wong 2011). In terms of language input, teacher talk functions as the input in the EFL classroom which is important for the process of language acquisition (Nunan 1991) and the active use of the target language by the students is considered to be an integral part of language acquisition process (Nunan 1999). However, there has been an interesting debate in SLA concerning the role of input.

Despite the debate, current SLA research appears to consider the language the teacher uses as a source of language input in instructional contexts ( Ellis 1994, Lightbown 1985, Long 1996, Littlewood \& Yu 2011). According to Krashen (1982), it is possible for the language learner to acquire the language without practicing talking, what is important is input. 'Input' refers to language addressed to learner through any means of delivery (Krashen 1985).

However, Ellis (1994), Long (1983), Swain (1985) argue that although language input is essential for acquisition, input alone is insufficient; another necessity for successful acquisition to occur is interaction. Interactions are important because learners can improve their language through interaction as they listen to their teachers, and then they can use all that they have learned for communication. This kind of activity is seen as promoting their language development which will lead to comprehensible output (Swain \& Lapkin 1995).

Maximising comprehensible language input as well as interaction is the ultimate goal in a language-learning situation, as this is an important aid to acquisition. Consequently, teachers should consider the language they use in the classroom, because the language they use function as the input and can serve to elicit output. On this basis, it is important to discuss teacher talk in FL classroom.

\section{Teacher talk in language classroom}

Despite the rich and contextual research on the role of teacher talk, much of the research on teacher talk has mainly focused on its amount (quantity) and mainly done in the classroom where language policy emphasizes the target language use. The notion of "teacher talk too much" has perhaps acted as barrier to evaluating teacher talk as language input. However, what may be important is not only so much the quantity of teacher talk, but also how teachers talk, what language they use, and whether they talk in the right kind of way to aid students' language development?

There are debates and arguments centred whether teachers should use TL strictly (e.g. Chambers 1992, Cummin 2007, Krashen 1985), or allow limited use of L1/SL as the medium of instruction in the EFL classroom (Anton \& DiCamilla 1998, Brook \& Donato, Cook 2001, Duff \& Polio 1990, Storch \& Wiggleworth 2003). Turnbull \& Arnett (2002) report their review of studies in several countries that teachers should aim to maximum use of the TL. A language classroom should be provided with an environment in which students can contribute to learning activities and maximise their use of the language (van Lier 2004).

There is no question that the use of the TL represents current mainstream thinking in the field of SL/EFL teaching where learners have little opportunity to hear and use the TL inside and outside the classroom (Ellis 1985, Dailey-O'Cain 2009). However, there also exists a body of literature in favour of some use of $L 1$ of the students with different views on the extent to which and the situation in which the L1 should be used (e.g. Atkinson 1985, Cook 2001, Storch \& Wigglesworth 2003). Raschka et al. (2009) discuss that aviodance of using the L1 is unlikely to occur, especially when the teacher ansd learners share the same first language. Their views imply that in practical terms teachers cannot avoid using the L1.

Although the literature states L1 use to some extent, various researchers have also warned of the detrimental effects of its over-use in EFL, and do not support its random use (Atkinson 1987, Raschka et al. 2009). Cook (2001) highlights that teachers need to ensure that there is a critical reflection around the moderate and judicious use of L1/SL in the language classroom. To put into practice these scholars ideas of the maximum and optimal use of L1 in a classroom is difficult (Zacharias 2011) since teachers sometimes do not realize themselves when they have used L1 (Polio \& Duff 1994).

Despite what language is used in the language classroom, it is important to judge or assess teacher-talk by reference to its quantity and its quality (Cullen 1998). Supporting Cullen (1998) and Thornbury (1996), Lei (2009: 75) 
notes that "good teacher talk as an input is evaluated in terms of its quality, not only quantity". This is due to state that there is a tendency for teachers to control the patterns of communication. In other word, the teacher decide who, when, how to talk in the classroom (Johnson 1995, Clifton 2006) and also the language they use in the classroom.

Some researches have investigated the syntactic aspects of teacher talk ( e.g. Gaies 1977, Wesche \& Ready 1985). Gaies concludes that the speech of those teachers in his research when speaking with their students was slower than that when speaking with their peers. Wesche \& Ready (1985) investigated the speech of an English professor and a French professor in two university psychology class. These two professor conducted the lesson in the student's second language, English or French. Both English professor and French professor significantly used more words and rephrased self-repetition with their L2 classroom than with their L1 classes. Ellis (1985) in his study counted the same teacher selfrepetitions on two occasions in classroom interactions with two ESL secondary beginners students, and found a significant decrease in frequency over an observation period of six months. His findings are in accordance with Gaies (1977) and Wesche \& Ready (1985) findings, where it seems that the teacher is able to make an implicit judgment about their students' levels in terms of their use of the language in the classroom.

Regarding the focus of this paper, it should be pointed out that the focus of the present paper is essentially on the techers' TL as an input, as well as on the use of the L1 within the foreign language context; teacher talk is the main language input available in the classroom and, its impacts on students' language output is critical. Neil (1977), Turnbull \& Arnetts (2002) and Singleton \& Ryan (2002) discusses a rationale for the use of TL in the language classroom. They conclude that the use of TL by the teacher improved the student's achievements. Their findings reveal that the role of the $T L$, as the language input leading to student TL language output, is critical. Hence, the students should be given opportunity to listen and then use the TL.

\section{Methodology}

The following section presents participants, data and data analysis of this study.

\section{Participants}

The participants of this study, both teachers and students, came from two elementary schools in Kota Padang, West Sumatra, Indonesia - Sekolah Dasar Percobaan Negeri Kota Padang and Sekolah Dasar Pembangunan UNP Padang. These schools have included English-language instruction in the curriculum for at least the last 10 years. The former is a pilot school for elementary schools in Kota Padang (Diknas No: 302/C2/DL/2009); the pilot school acts as a testing ground for subject, curriculum and methodology development, and as a model for elementary schools in the surrounding Kota Padang area. It is located in the centre of Padang City. The latter is linked to the Padang State University and the program offered there is developed in accordance with the university; thus, English faculty members from the university are represented in the English-language program at the school.

There were three teachers participating in this research from the two elementary schools mentioned above: one teacher from grade 5 and one teacher from grade 6 of Sekolah Dasar Percobaan Padang, and one teacher who taught grade 5 and 6 of Sekolah Dasar Pembangunan Padang.

The number of students in each class participating in this research ranged from 20 to 25 . One of the aims of this research was to investigate student language output; Grade 5 and 6 students had been selected on the assumption that students from these two grades, having received significantly more instruction in English language, produced more output than students from lower grades.

The classes selected for classroom recordings were the ones in which teacher $A, B$, and C taught English. Three classes chosen for this study were bilingual classes in which the students spoke Minangkabau language as their L1 and Bahasa Indonesia as their SL and were learning English as TL. All classes were mixed -ability classes with different levels of English competence.

All the participating students were between 10 to 12 years of age. The majority did not have an English-speaking background, except that they had learned English from first grade in elementary school. They learned English once a week, each period being 70 minutes long. Effectively, the two schools run for 34 weeks a year; thus, they have potentially had 132 sessions of English-language instruction. 


\section{Data}

The data were collected in a 7-week period over the second semester in 2013 from early January till end of February 2013. The researcher visited each school on a weekly basis. Each classroom session was 70 minutes per week. Some classroom visits, however, were cancelled due to public holidays and schools events such as pre-final exam and religious events. The total number of visits varied between three teachers. It was difficult to reschedule a visit for the same week because English subject was taught once a week. As a result, the researcher conducted a total of 20 classroom observations. These observations were video recorded.

\section{a. Video-recording of classroom sessions}

Data concerning teacher-student interaction during the class was collected by means of video-recording. The recordings were taken place in the natural setting of the classroom, where the researcher was visible to both students and the teacher, and they all knew the reason for the researcher's presence in the classroom. One camera focused on the teacher, but was set at a wide enough angle to video-record the entire class. Another camera was placed on the teacher's table in front of the class, facing the students for the purpose of recording student participants. Although all the three teachers had two classes to teach, only one of their classes was chosen to be video-recorded. This class was chosen randomly. Accordingly, in total there were 21 hours of video recordings.

The recordings focused on the teacher's and student's language selection and thus were limited to interactions between the teacher and the student(s). An important consideration in the design of this study was to measure teachers and students as they were addressing and interacting each other as a class rather than when the students were working together in pairs or small groups. The data, therefore, did not include recordings of interaction among students, in pair or group activities.

\section{b. Detailed note-taking}

It was anticipated that technical problems might arise with the video camera on some occasions and some phenomena might not be well captured by it. For this purpose, the researcher took detailed notes or photos during the class, describing classroom events, commenting on their functions as they were observed. Anything that was written on board was also written down (photo), alongside who wrote it. These extra pieces of information turned out to be very useful during the transcribing and analysing of the video recordings, helping the researcher to recall the incidents more easily and also to be able to put some of the incidents into the wider contexts.

\section{c. Stimulated recall interviews}

In the present study, the stimulated recall interview was used for two reasons: to prompt the teacher to reflect on her teaching practice; and to investigate the teacher's specific reasons for using particular instances (utterances) of Bahasa Indonesia (SL) or English (TL) at particular points in the course of their teaching. The stimulated recall interviews were semi-structured, with a set of questions guiding the interviews. The researcher asked teachers how often they believe they used English during the class, why they changed to SL or TL in certain instances, and what their general teaching philosophy was in relation to the language of choice in the classroom. The participants were given the option to be interviewed in English or Bahasa Indonesia. They chose Bahasa Indonesia. Both the researcher and the teacher were freed at any time to stop the recording to provide comment.

The interviews took place after the completion of the entire set of classroom recordings in order that the interview questions do not influence the teachers' classroom practice. The researcher selected two lessons for each teacher which contained the greatest amount of teacher-student verbal interaction. Thus, each of the selected lessons represented a rich sample of teacher talk. Nunan (1992) notes that this technique has at least two advantages: to produce insights into the teaching and learning process, which would be hard to obtain by other means; and to make the class participants' voice heard.

\section{d. Data analysis}

The present study investigated the classroom discourse in terms of what the language used by the teacher and its impact 
on the students' language output in terms of language used. The quantitative analysis was used to document the teachers' language choices. The qualitative analysis was used to analyse the recordings of classroom interaction, the stimulated interview and the field notes taken during the recordings of classroom interaction to see which teacher among the three teacher participants who could elicit more students' output. It was also used to see what impact teachers' language choice has on the students' language output in terms of the language used.

Therefore, a more open exploration of the data was required, which suggested favouring a Conversation Analysis (CA) approach. CA can help pictures what actually happens in the classroom which largerly determines the degree to which learning and learning outcomes are realised (Kumaradivelu 1999). The data were transcribed and contextually relevant information was also provided in the transcript.

A word count method was used to determine the amount of spoken language in the classroom, and the distribution of the two different language Bahasa Indonesia (SL) and English (TL) in the speech of the teachers and the students. This analysis was carried out in order to be able to find out what language teachers used most in the EFL classroom, English (SL) or Bahasa Indonesia (TL). Further analysis using qualitative analysis was applied to find out what really happened in Teacher A, Teacher B and Teacher $\mathrm{C}$ class. This analysis made it possible to make systematic comparisons amongs the different teachers to find out what impact does the teacher's language use have on students' language output.

\section{Results/ discussion}

The percentage for the teacher's choice of language types are presented in the following tables. These tables present the amount of teacher talk in 4 sessions and their respective classes as counted as prencentage of the total number of words spoken by the three teachers and their respective class in particular language. In this research teacher talk consists of two languages in the classroom, Bahasa Indonesia (SL) and English (TL).

\section{Language use in the classroom discourse}

Tabel 1. The percentage of SL+TL used in 4 lessons

\begin{tabular}{|l|l|l|}
\hline \multirow{3}{*}{ Bahasa Indonesia (SL) + English (TL) } & Teacher & Students \\
\cline { 2 - 3 } & $(\%)$ & $(\%)$ \\
\cline { 2 - 3 } & $80.5 \%$ & $19.5 \%$ \\
\hline
\end{tabular}

Table 1 displays the quantity of words the teachers and the students used, Bahasa Indonesia (SL) and English (TL). Of the total number of words spoken in the class during teacher and students interactions in whole class activities accounted for $80.5 \%$ of the SL and TL spoken by the teachers. It means that the students accounted for only $19.5 \%$ of Bahasa Indonesia and English spoken in the classroom. It can be concluded that teachers in this research used more words than their students in Bahasa Indonesia and English. Although it is important not to interpret these results as the word estimate are approximate, the results do indicated that the teachers dominate the classroom discourse in 4 lessons. This finding is similar to previous studies in teacher talk (Polio \& Duff 1994, Macaro 2001, Rolin-lanziti \& Bronlie 2002, Morata 2011) that student talk accounts for an average of less than $30 \%$ of talk in classroom discourse.

It should be also noted that the classes appeared to be very much teacher-centred and the data obtained support this notion. Not only did teachers direct all of the activities, but they spent much more time speaking than the students. This finding appears contradict one of the current trends in language teaching where teachers are encourage to develop a more student-centered classroom (see van Lier 2001, Paul 2003). Further analysis was done to look at what language were teachers used most, SL or TL.

Table 2 presents the percentage of teacher talk in 4 sessions of each teacher as counted as percentages of the total number of words spoken by three teachers in SL and TL. 
Table 2. The percentage of SL and TL used in 4 sessions.

Teacher talk

\begin{tabular}{|l|l|}
\hline $\mathrm{SL}$ & $\mathrm{TL}$ \\
\hline$(\%)$ & $(\%)$ \\
\hline $33.7 \%$ & $66.4 \%$ \\
\hline
\end{tabular}

Table 2 shows that the three teachers observed used $33.7 \%$ of SL and $66.4 \%$ of TL. These percentages are similar in terms of the use of the target language (English), in comparison with the study by Duff \& Polio (1990). The two teachers reported by Duff \& Polio (1990) used the target language in class for $10 \%$ and $68 \%$ of the time. However, there were differences found between the three teachers observed in this study in the amount of SL and TL spoken by each teacher. The three teachers showed a great deal of variation between their use of SL and TL. The following table 3 shows the difference of teacher talk among the three teachers observed and their respective classes.

Tabel 3. The percentage of SL and TL spoken among the three teachers and their respective class

\begin{tabular}{|l|l|l|}
\hline Participants & \multicolumn{2}{|l|}{$\begin{array}{l}\text { English (TL) Percentage } \\
(\%)\end{array}$} \\
\hline & Teacher & Students \\
\hline Teacher A & $71.1 \%$ & $28.9 \%$ \\
\hline Teacher B & $86 \%$ & $14 \%$ \\
\hline Teacher C & $73 \%$ & $27 \%$ \\
\hline
\end{tabular}

Table 3 reveals that Teacher A and Teacher C elicited more students' output in TL ( $28.9 \%$ and $27 \%$, respectively); on the other hand Teacher B used more TL than Teacher A and Teacher C, but she elicited the least students's TL output. In this sense, the comparison of the three teachers in their used of SL + TL, SL and TL is needed. The following table shows the language used by the three teachers.

Tabel 4. The percentage of SL+TL, SL and TL spoken among the three teachers.

\begin{tabular}{|l|l|l|l|}
\hline \multirow{2}{*}{ Participants } & \multicolumn{2}{|l|}{$\begin{array}{l}\text { Percentage } \\
(\%)\end{array}$} & \multicolumn{2}{|l|}{} \\
\cline { 2 - 4 } & SL + TL & TL \\
\hline Teacher A & $12.7 \%$ & $17.3 \%$ & $3.11 \%$ \\
\hline Teacher B & $42.3 \%$ & $58.3 \%$ & $8.9 \%$ \\
\hline Teacher C & $45 \%$ & $24 \%$ & $88 \%$ \\
\hline
\end{tabular}

Table 4 reveals that among the three teachers, Teacher A spoke the least (SL+TL, 12.7\%). Referring to table 3 above, it is clear that Teacher A elicited the most students' TL output (28.9\%). This results indicated that much TL output spoken by the students is associated with much TL spoken by the teacher and small amount of SL spoken by the teacher in the classroom. It is interesting to note in table 4 that Teacher B and Teacher $C$ used even more target language than Teacher A, however they elicited less students' TL output than Teacher A. Interpreting these results only might misslead the research conclusion. Therefore, it is important to know what really happened in each teacher's participant class. For this purpose, Conversation Analysis was used to further analyse the recordings of the classroom interaction between each teacher and her respective class. The section that follows presents teacher language used and its impact on the students' language output. 


\section{Teachers' language input and students' language output.}

In terms of student-teacher interaction, Teacher A avoided to give long and tedious word explanation. She preferred to use other teaching aids such as visual aids in explaining., e.g picture (extract 1) rather than long explanation. In addition, she also provided the students with translation on the whiteboard as part of the input. She believed that if she gave various types of input, it will gave the students time to save the explanation into their long term memory. Munoz (2008) discusses that in addition to the amount of exposure to the target language as an input, it is also necessary to consider the type of input available for the learner. Thus, it is important to identify types of input as well as the quantity of the input. Moreover, when teaching and explaining a new word, Teacher A avoided to give long and tedious word explanation in Bahasa Indonesia (SL). She said that SL could be used to provide a quick translation of an English word which might take time for her to explain. She gave explain the lesson most of the time in English (TL). Accordingly, she provided the students with much exposure to the target language. According to Dekeyeser (2000) and Munoz (2008), younger leaners' memory approach to learning requires a great amount of input, which means that much exposure to the target language is important.

Following is an extract of Teacher's A classroom discourse.

Extract 1. Teacher's A extract of classroom discourse

\begin{tabular}{|l|l|}
\hline SPEAKER & UTTERANCE (S) \\
\hline T & What about this? ((the teacher points to the picture of the Governor in her hand)) \\
\hline S & Governor \\
\hline T & Governor, ((the teacher repeats the students utterance)), this? ((point to the picture of the mayor in her hand)) \\
\hline T & Can you tell again? ((the teacher shows the picture of the governor and the mayor to the students)) \\
\hline SS & Yes, yes \\
\hline S & Governor \\
\hline S & Mayor \\
\hline T & Do you know what picture is this? ((the teacher shows the picture of a king, queen, emperor )) \\
\hline
\end{tabular}

On the other hand, Teacher B and Teacher $C$ gave a long explanation in words (see extract 3 and extract 2, respectively). The difference among these two teachers is Teacher $\mathrm{B}$ gave the explanation in the target language, while it is obvious in extract 2 that Teacher C preferred to use Bahasa Indonesia (SL). Teacher C used SL to explain the lesson to avoid misunderstanding. This finding is in contrast to Ellis (2005: 10) who emphasizes that "everything the teacher does or says in the L2 classroom provides an opportunity for learning the new language, and use of L1 deprives students from valuable opportunities to use, communicate, and process L2". The use of SL might facilitate the learner' understanding, but it hindered their progrees in productive competence (Khanal 2004) especially in the context of EFL learning where the apportunities to listen and to use the TL is limited (Musumeci 1996).

Extract 2. Teacher's $C$ extract of classroom discourse

\begin{tabular}{|c|c|}
\hline SPEAKER & UTTERANCE (S) \\
\hline $\mathrm{T}$ & $\begin{array}{lcc}\text { Kemaren } & \text { skillnya berbicara menggunakan "who" } \\
\text { [Yesterday] } & \text { [speaking] [using] }\end{array}$ \\
\hline $\mathrm{S}$ & "Who" \\
\hline $\mathrm{T}$ & $\begin{array}{l}\text { Ya, "who" sekarang kita berbicara tentang skill menulis, jadi nanti } \\
\text { [Yes] [now] [we] [talk] [about] [writing], [so] [later] } \\
\text { disamping anak mam bisa mengungkapkannya dalam berbicara, } \\
\text { [beside] [child] [able] [say] [it] [in] [speaking] } \\
\text { anak mam juga bisa menggunakannya dalam menulis. } \\
\text { [Child] [also] [able] [to use] [it] [in] [writing] } \\
\text { ((the teacher writes "asking and giving information" on the whiteboard)) } \\
\text { ok, jadi kita semua sudah belajar, "asking and giving information } \\
\text { [so] [we] [all] [already] [learned] } \\
\text { by." }\end{array}$ \\
\hline
\end{tabular}




\begin{tabular}{|c|c|}
\hline & $\begin{array}{l}\text { menggunakan, apa nak? by using apa kita gunakan kemaren? } \\
\text { [to use] [what] [child] [what] [we] [use] [yesterday?] } \\
\text { menggunakan apa anak anak? } \\
\text { [to use] [what] [kids?] } \\
\text { ((the teacher writes "asking and giving information" on the whiteboard)) }\end{array}$ \\
\hline $\mathrm{S}$ & where, when, who, what, \\
\hline $\mathrm{T}$ & $\begin{array}{l}\text { where, when, who, what,((the teacher repeats the student while writing on the board)) ya, } \\
\text { sekarang kita liat lagi kalau what kita } \\
\quad \text { [yes], [now] [we] [see] [again] [if] } \quad \text { [we] } \\
\text { gunakan untuk apa? } \\
\text { [use] [for] [what?] }\end{array}$ \\
\hline $\mathrm{S}$ & $\begin{array}{l}\text { What, apa } \\
\text { [what] }\end{array}$ \\
\hline $\mathrm{T}$ & 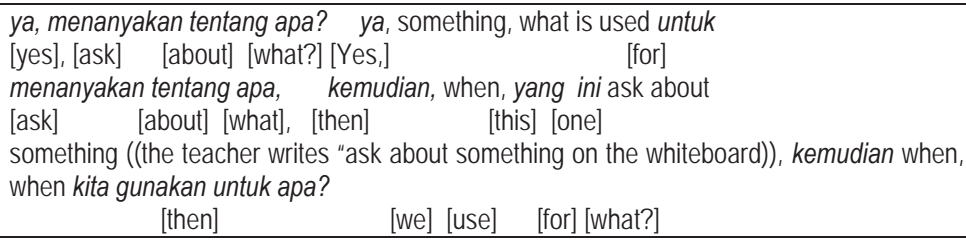 \\
\hline
\end{tabular}

In extract 3, it is clear that teacher B used much English in her teaching, however, her target language used was considered poor, for example in her utterances in extract 3, "And first, actually, home, they are different, do you know what is different? do you know different meaning?". It was not really clear what did Teacher B mean by the word "different", because within the next turn, she also used the word "different" in her utterance but for different puopose.

\section{Extract 3. Teacher's B extract of classroom discourse}

\begin{tabular}{|l|l|}
\hline Speaker & Utterance (s) \\
\hline$T$ & $\begin{array}{l}\text { And first, actually, home, they are different, } \\
\text { do you know what is different? do you know different meaning? }\end{array}$ \\
\hline S & $\begin{array}{l}\text { Perbedaan } \\
\text { Difference }\end{array}$ \\
\hline$T$ & $\begin{array}{l}\text { Ya, good, perbedaan } \\
\text { [Yes] } \\
\text { what is the different about has got and has? ok, look at this, I have got or l've got the flu, means the piggy } \\
\text { has the flu, this one is the picture, ok, can you see? } \\
(\text { (the teacher shows the picture of a pig)) }\end{array}$ \\
\hline S & Yes \\
\hline T & What is that? \\
\hline S & Pig, pig, pig \\
\hline$T$ & $\begin{array}{l}\text { Pig, ok, good, I have got or l've got the flu, means the piggy has a flu, ok, next, ok, you can see here the } \\
\text { meaning is the fear, } \\
\text { I have the flu means the piggy have the flu, can you see the different? }\end{array}$ \\
\hline S & Yes \\
\hline T & $\begin{array}{l}\text { But the meaning is still the same,ok? next, today you can see in your books too, we will discuss about kinds } \\
\text { of illness by using have got or has got, number one, cough, what is cough? yes? }\end{array}$ \\
\hline S & $\begin{array}{l}\text { Demam? } \\
\text { [cold] }\end{array}$ \\
\hline
\end{tabular}

It is obvious that Teacher's A students produced more TL as a language output than Teacher's B and Teacher's C students. The interpretation given to these results was that the amount of exposure to the target language may have strong impact on the students' language output. These findings are similar to the findings of Carrol (1975), Meng \& Wang (2011). The teacher's use of the target language in the context of EFL classroom can help leaners obtain effective input 
and output through communication. Overall, the teachers in this study used of Bahasa Indonesia (SL) was more than they expected to use. They used $33.7 \%$ of Bahasa Indonesia where as according to Atkinson (1987), Calman \& Daniel (1998) and Turnbull (2001), the productive use of L1/SL is $5 \%$.

\section{Conclusion and suggestion}

In conclusion, it has become clear that the use of Conversation Analysis in looking at the teacher and the students language use in the EFL classroom is appropriate as it can picture what really happened in the classroom. Teachers in this study used more English in class than their students did. Furthermore, it can be also concluded that the highest amount of Teacher's A target language use influenced her students' target language output. The current study also reveals that the participating teachers also used Bahasa Indonesia (SL) in their teaching, but vary in amount. Based on thses resuls it is suggested that teachers need to be aware of the language they use in the classroom discourse. Teachers are called to consider not only the maximum and optimal use of TL but also in terms of the quality of its use.

Notes for transcription:

Italic = Bahasa Indonesia (SL)

$(())=$ Context

[ ] = Translation from SL to TL

\section{References}

Anton, M., \& DiCamilla, F. (1998). Socio-cognitive functions of L1 collaborative interaction in the L2 classroom. Canadian Modern Language Review, 54, 314-342.

Atkinson, D. (1987). The mother tongue in the classroom: A neglected resource. English Language Teaching Journal, 41, 241-247.

Brook, F. B., \& Donato, R. (1994). Vygotskyan approaches to understanding foreign language learner discourse during communicative tasks. Hispania, 77, 262-274.

Carrol, J.B. (1975). The teaching of French as a second language in eight countries. New York: John Wiley

Chambers, G. (1992). Teaching in the target language. Language Learning Journal, 6, 6-7.

Clifton, J. (2006). Facilitator talk. Vol. 60. Oxford: Oxford University Press, (p. 142).

Cook, V. (2001). Using the first language in the classroom. Canadian Modern Language Review, 57, 402-423.

Cullen, R. (1998). Teacher talk and classroom context. ELT Journal, 52, 179-187.

Cummins, J. (2007). Rethinking monolingual instructional strategies in multilingual classrooms. Canadian Journal of Applied Linguistics, $10,221-240$

Dailey-O'Cain, J. and Liebscher, G. (2009) 'Teacher and learner first language use in foreign language classroom interaction: Functions and applications', in Turnbull, M. and Dailey-O'Cain, J. (Eds), First language use in second and foreign language learning. Clevedon,: Multilingual Matters, pp. 131-186.

Depdikbud RI (Department of Education and Culture Republic of Indonesia). (1993). The Decree of the Minister of Education and Culture No. 060/U/1993.

Depdiknas RI (Departement of Education Republic of Indonesia). (2006). KurikulumTingkat Satuan Pendidikan Bahasa Inggris untuk SD/MI (KTSP) (School Based English Curriculum for Elementary School). Jakarta: Departemen Pendidikan

Nasional.

Dekeyeser, R. (200). The robustness of critical period effects in second language acquisition. Studies in Second Language Acquisition, 22, 499-533.

Diknas (Department of Education, Province). (2010). Laporan Workshop Peningkatan Pembelajaran Bahasa Inggris, Kerjasama Diknas dan Australia. Unpublished report of workshop on improving English teaching, Diknas and Australia. Padang: DiknasPendidikan.

Duff, P.A., \& Polio, C.G. (1990). How much foreign language is there in the foreign classroom? The Modern Language Journal, 74, 154166.

Ellis, R. (1994). The study of second language acquisition. Oxford: Oxford University Press.

Gaies, S.J. (1977). The nature of linguistic input in formal second language learning: Linguistic and communicative strategies in teachers' classroom language. In H. D. Brown, C. A. Yorio, \& R. H. Crymes (Eds.), On TESOL '77. Washington, DC: TESOL.

Gaies, S. J. (1983). Learner feedback: An exploratory study of its role in the second language classroom. In H. W. Seliger \& M. H. Long (Eds.), Classroom oriented research in second language acquisition (pp. 190-213). Cambridge, MA: Newbury House.

Johnson, K.E. (1995). Understanding communication in second language classrooms.Cambridge: Cambridge University Press.

Khanal, K. (2000). A study on the use of Nepali language in English classroom. An Unpublished M.Ed. Thesis. Kathmandu: Tribuvan University

Krashen, S. (1982). Principles and practice in second language acquisition. New York: Pergamon Press 
Krashen, S. (1985). The input hypothesis: Issues and implications. New York: Longman.

Lei, X. (2009). Communicative teacher talk in the English classroom. English Language Teaching, 2, 75-79.

Long, M. H. (1983). Native speaker/non-native speaker conversation and the negotiation of comprehensible input. Applied Linguistics, 4 , 126-141

Long, M. H. (1996). The role of the linguistic environment in second language acquisition.In W. C. Ritchie \& T. K. Bhatia (Eds.), Handbook of Second Language Acquisition (Vol. 2) (pp. 413-468). New York: Academic Press.

Littlewood, W.,\& Yu, B. (2011). First language and target language in the foreign language classroom. Language Teaching, 44, 64-77.

Meng, X., \& Wang, X. (2011). Action study of teacher's language on EFL classroominteraction. Theory and Practice in Language Studies, 1, 98-104.

Macaro, E. (2001). Analysing students teachers' code switching in foreign language classrooms: Theories an decision making. Modern Language Journal, 85, 531-548.

Morata, M., \& Coule, Y. (2012). Teaching English through Spanish: A secondary school EFL teachers' language choices in the foreign language classroom. Porta Linguarium, 17, 133-152.

Munoz, C. (2008). Symmetries and asymmetries of age effects in naturalistic and instructed L2 Learning. Applied Linguistics, 18, 1-19.

Musumeci, D. (1996). Teacher-learner negotiation in content-based instruction: Communication at cross-purposes? Applied Linguistics, 17, 286-325.

Nation, P. (1997). L1 and L2 use in the classroom: A systematic approach. TESL Reporter, 30(2), 19-27.

Neil, P. S. (1997). Language teaching methodology: A textbook for teachers. Englewood Cliffs: Prentice Hall.

Nunan, D. (1991). Language teaching methodology. Hertfordshire: Prentice Hall International.

Nunan, D. (1992). Research methods in language learning. Cambridge: Cambridge University Press.

Nunan, D. (1999). Second language teaching and learning. Heinle \& Heinle.

Paul, D. (2003). Teaching English in Children in Asia. Asia: Longman.

Polio, C., \& Duff, P. (1994). Teacher's language use in university foreign language classroom: A qualitative analysis of English and target language alternation. Modern Language Journal, 78, 313-326.

Raschka, C. Sercombe, P. \& Chi-Ling, H. (2009). Conflicts and tensions in codeswitching in a Taiwanese EFL classroom. International Journal of Bilingual Education and Bilingualism, 12(2), 157-171.

Rolin-lanziti, J., \& Brownlie, S. (2002). Teacher use of learners' native language in the foreign language classroom. The Canadian Modern Language Review, 58, 402-426.

Singleton, D., \& Ryans, L. (2004). Language acquisition: The age factor (2nd Ed.) Clevedon: Multilingual Matters.

Storch, N., \& Wigglesworth, G. (2003). Is there a role for the use of the L1 in a L2 setting? TESOL Quarterly, 37, 760-770.

Swain, M. (1985). Communicative competence: Some roles of comprehensible input and comprehensible output in its development. In S. M. Gass, \& C. G. Madden (Eds.), Input in second language acquisition (pp. 235-256). Rowley, Mass.: Newbury House Publishers.

Swain, M. (1995). Three functions of output in second language learning. In G. Cook \& B. Seidlhofer (Eds.), Principles and practice in applied linguistics: Studies in honor of H.G. Widdowson (pp. 125-144). Oxford: Oxford University Press.

Turnbull, M., \& Arnett, K. (2002). Teacher's uses of the target language and first languages in second and foreign language classrooms. Annual Review of Applied Linguistics, 22, 204-218.

Wesche, M. \& Ready, D. (1985). Foreigner talk in the university classroom. In S. M. Gass, \& C. G. Madden (Eds.), Input in second language acquisition (pp. 89-114). Rowley, Mass.: Newbury House Publishers.

Wong, R. M. H. (2011). Developing teacher awareness of language use and language knowledge in English classroom: Four longitudinal cases. Electronic Journal of Foreign Language Teaching, 8, 19-38.

van Lier, L. (2001). Constraints and resources in classroom talk: Issue of equality and symmetry. In Candlin and Mercer (pp. 90-107).

Zacharias, N.T. (2011). An English teacher struggle to establish voice in the periphery.k@ta, 13(1),64-77 